\title{
GAMBARAN KECEMASAN TERHADAP PENAMBALAN GIGI PADA ANAK UMUR 6 - 12 TAHUN DI POLI GIGI DAN MULUT PUSKESMAS TUMINTING MANADO
}

\author{
${ }^{1}$ Melisa Wuisang \\ ${ }^{2}$ Paulina Gunawan \\ ${ }^{3}$ Joyce Kandou \\ ${ }^{1}$ Kandidat Skripsi Program Studi Pendidikan Dokter Gigi Fakultas Kedokteran \\ ${ }^{2}$ Program Studi Pendidikan Dokter Gigi Fakultas Kedokteran \\ ${ }^{3}$ Bagian Psikiatri Fakultas Kedokteran \\ Universitas Sam Ratulangi \\ Email: melisawui@yahoo.com
}

\begin{abstract}
Dental anxiety is the cause of psychological disorders such as depression, anxiety, and discomfort for dental care, especially in dental fillings. Dental anxiety in dental fillings is an obstacle that can lead to negative effects on patients, especially in pediatric patients. This study was conducted to obtain patients' anxiety before dental fillings. This was a descriptive study with a total sampling method. Total sample of 50 pediatric patients aged 6-12 years consisted of 28 girls and 22 boys. Data were collected by using questionnaires Dental Anxiety Scale (DAS) before performing the dental fillings. The results showed that there were 17 girls (60.69\%) and 6 males (27.27\%) that experienced severe anxiety. Most severe anxiety was experienced by youngest aged children - the youngest age was 6 years.
\end{abstract}

Keywords: children anxiety, dental fillings

\begin{abstract}
Abstrak: Kecemasan dental adalah penyebab dari gejala gangguan psikologis seperti depresi, ketakutan, dan perasaan tidak nyaman terhadap perawatan gigi terutama dalam penambalan gigi. Kecemasan dental dalam penambalan gigi merupakan halangan yang dapat mengakibatkan efek negatif pada pasien terutama pada pasien anak. Penelitian ini dilakukan untuk melihat gambaran kecemasan pasien anak yang berusia 6-12 tahun sebelum melakukan proses penambalan gigi. Penelitian ini bersifat deskriptif dengan metode total sampling. Jumlah sampel 50 pasien anak berusia 6-12 tahun yang terdiri dari 28 anak perempuan dan 22 anak laki - laki. Data diambil menggunakan kuisioner Dental Anxiety Scale (DAS) sebelum dilakukan prosedur penambalan gigi. Hasil penelitian memperlihatkan pada kelompok anak perempuan yang mengalami cemas berat sebesar 17 sampel $(60,69 \%)$ dan pada kelompok anak laki-laki sebesar 6 sampel $(27,27 \%)$. Kecemasan berat paling banyak dialami oleh anakanak yang umurnya paling muda yaitu 6 tahun dengan 6 sampel mengalami cemas berat dari total 8 sampel.
\end{abstract}

Kata kunci: kecemasan anak, penambalan gigi

Kecemasan merupakan keadaan normal yang dialami secara tetap sebagai bagian perkembangan normal manusia yang sudah mulai tampak sejak masa anak - anak. ${ }^{1}$ Kecemasan sering ditandai dengan gejala perasaan yan tidak enak, tidak berdaya, dan serangkaian reaksi emosional negatif lainnya, seperti frustasi, ketakutan, kemarahan, penarikan diri dan depresi. ${ }^{2}$ Dalam bidang kedokteran gigi, gejala kecemasan seringkali ditemui pada anak yang melakukan perawatan gigi khususnya 
penambalan gigi. Bahkan sebelum proses penambalan gigi, rasa cemas dan rasa takut muncul dalam benak anak - anak karena imajinasi anak itu sendiri. ${ }^{3}$

Kecemasan pada anak yang melakukan penambalan gigi juga akan semakin memburuk karena praktek dokter gigi memiliki suasana dan peralatan yang asing. ${ }^{4}$ Kecemasan yang dialami oleh anak - anak adalah hasil yang berlebihan terhadap reaksi emosi, turun naiknya emosi memang hal yang wajar bagi proses psikologi seseorang tetapi ada beberapa orang yang merasa lebih tertekan oleh tekanan emosionalnya daripada orang lain sehingga mengakibatkan kecemasan.,6

Kecemasan dapat dipandang sebagai tanda bahaya dari segi biologis dan psikologis, dari segi fisiologis kecemasan terjadi sebab libido yang terbendung. ${ }^{7}$ rasa cemas terhadap penambalan gigi dari segi psikologis biasanya terjadi karena adanya persepsi nyeri tetapi rasa nyeri juga akan bisa menimbulkan rasa cemas. ${ }^{8}$

Dalam penelitian ini penulis mengambil lokasi di Poliklinik Gigi dan Mulut Puskesmas Tuminting Manado. Dengan mempertimbangkan beberapa faktor seperti belum adanya penelitian tentang tingkat kecemasan anak berumur 6 - 12 tahun terhadap penambalan gigi di Puskesmas Tuminting Manado, serta ketersediaan pelayanan poliklinik terhadap penambalan gigi yang telah memadai sehingga memungkinkan pengambilan data yang lebih baik dan akurat.

\section{BAHAN DAN METODE PENELITIAN}

Rancangan penelitian ini merupakan penelitian deskriptif dengan desain potong lintang. Penelitian dilaksanakan di Poliklinik Gigi dan Mulut Puskesmas Tuminting Manado, Sulawesi Utara. Populasi penelitian ialah pasien anak berusia 6-12 tahun yang melakukan prosedur penambalan gigi di Poliklinik Gigi dan Mulut Puskesmas Tuminting Manado, Sulawesi Utara. Pengambilan sampel menggunakan teknik total sampling, yaitu seluruh pasien yang akan melakukan penambalan gigi di Poliklinik
Gigi dan Mulut Puskesmas Tuminting Manado pada bulan November 2014 yang berjumlah 50 pasien.

Kriteria inklusi yaitu pasien anak yang bermur 6-12 tahun yang akan melakukan prosedur penambalan gigi dan yang bersedia untuk menjadi subjek dalam penelitian ini dengan mengisi formulir dan menandatangani informed consent. Kriteria eksklusi yaitu pasien yang mengalami cacat mental. Instrumen Penelitian untuk menilai tingkat kecemasan anak ialah lembar kuisioner DAS (Dental Anxiety Scale) yang terdiri dari 5 penilaian skor kecemasan anak yaitu : $\mathrm{A}=1, \mathrm{~B}=2, \mathrm{C}=3, \mathrm{D}=4, \mathrm{E}=$ 5 dengan jumlah total nilai $4-8=$ tidak cemas, $9-12=$ tingkat kecemasan ringan, $13-14=$ tingkat kecemasan sedang, 15 20 tingkat kecemasan berat.

\section{HASIL PENELITIAN}

Karakteristik subjek penelitian dikategorikan menurut jenis kelamin menunjukkan subjek penelitian berjumlah 50 orang yang terdiri dari 28 perempuan (56\%) dan 22 laki - laki (44\%). Data pada Tabel 1 pasien anak perempuan yang berumur 6 tahun terdapat 5 sampel (10\%), tahun 10 sampel (20\%), 8 tahun 6 sampel (12\%), 9 tahun 3 sampel (6\%), 10 tahun 2 sampel (4\%), 11 tahun 1 sampel (2\%) dan 12 tahun 1 sampel (2\%). Pada golongan anak laki - laki 6 tahun terdapat 3 sampel (6\%), 7 tahun 5 sampel (10\%), 8 tahun 2 sampel (4\%), 9 tahun 1 sampel (2\%), 10 tahun 6 sampel (12\%), 11 tahun 1 sampel (2\%), dan 12 tahun 4 sampel (8\%).

Data pada tabel 2 menunjukan bahwa pada pasien anak berjenis kelamin perempuan yang berumur 6 tahun tidak terdapat sampel pada tingkat kecemasan tidak cemas, ringan dan sedang dan terdapat 5 sampel $(17,85 \%)$ yang mengalami cemas berat. Pada anak perempuan berumur 7 tahun terdapat 3 sampel $(10,71 \%)$ yang tidak mengalami kecemasan, tidak ada sampel pada cemas ringan, 1 sampel (3,57\%) pada cemas sedang, dan 6 sampel $(21,46 \%)$ pada cemas berat. Pada umur 8 tahun tidak ada sampel 
untuk anak perempuan yang tidak mengalami kecemasan, terdapat masing masing 1 sampel (3,57\%) mengalami cemas ringan dan sedang, dan 4 sampel $(14,28 \%)$ pada anak cemas berat. Pada umur 9 tahun tidak terdapat sampel yang tidak mengalami kecemasan, 2 sampel $(7,14 \%)$ mengalami cemas ringan, tidak ada sampel untuk anak yang tidak mengalami kecemasan, 1 sampel (3,57\%) pada anak yang mengalami cemas berat. Pada anak berumur 10 tahun terdapat masing - masing 1 sampel (3,57\%) yang tidak mengalami kecemasan dan yang mengalami cemas ringan, dan pada anak yang mengalami tingkat kecemasan sedang dan berat masing - masing tidak terdapat sampel. Pada anak yang berumur 11 tahun masing - masing tidak terdapat sampel pada anak yang tidak mengalami kecemasan, yang mengalami kecemasan ringan, dan yang mengalami kecemasan sedang, terdapat 1 sampel (3,57\%) pada anak yang mengalami cemas berat. Pada anak perempuan yang berumur 12 tahun terdapat 1 sampel (3,57\%) tidak mengalami kecemasan, dan tidak terdapat sampel pada masing - masing tingkat kecemasan ringan, tingkat kecemasan sedang, dan tingkat kecemasan berat.

Tabel 1. Distribusi subjek penelitian berdasarkan umur dan jenis kelamin

\begin{tabular}{ccccccc}
\hline \multirow{2}{*}{ Umur (Tahun) } & \multicolumn{3}{c}{ Jenis Kelamin } & \multicolumn{2}{c}{ Total } \\
\cline { 2 - 7 } & $\mathbf{( n )}$ & $\mathbf{( \% )}$ & $\mathbf{( n )}$ & $\mathbf{( \% )}$ & (n) & (\%) \\
\hline 6 & 5 & 10 & 3 & 6 & 8 & 16 \\
7 & 10 & 20 & 5 & 10 & 15 & 30 \\
8 & 6 & 12 & 2 & 4 & 8 & 16 \\
9 & 3 & 6 & 1 & 2 & 4 & 8 \\
10 & 2 & 4 & 6 & 12 & 8 & 16 \\
11 & 1 & 2 & 1 & 2 & 2 & 4 \\
12 & 1 & 2 & 4 & 8 & 5 & 10 \\
\hline Total & 28 & 56 & 22 & 44 & 50 & 100 \\
\hline
\end{tabular}

Tabel 2. Distribusi subjek penelitian tingkat kecemasan berdasarkan jenis kelamin perempuan

\begin{tabular}{|c|c|c|c|c|c|c|c|c|c|c|c|c|c|c|c|c|}
\hline \multirow{3}{*}{$\begin{array}{c}\text { Tingkat } \\
\text { Kecemasan }\end{array}$} & \multicolumn{14}{|c|}{ Perempuan } & \multicolumn{2}{|c|}{ Total } \\
\hline & \multicolumn{2}{|r|}{6} & \multicolumn{2}{|r|}{7} & \multicolumn{2}{|r|}{8} & \multicolumn{2}{|r|}{9} & \multicolumn{2}{|c|}{10} & \multicolumn{2}{|c|}{11} & \multicolumn{2}{|c|}{12} & & \\
\hline & $\mathbf{n}$ & $\%$ & $\mathbf{n}$ & $\%$ & $\mathbf{n}$ & $\%$ & $\mathbf{n}$ & $\%$ & $\mathbf{n}$ & $\%$ & $\mathbf{n}$ & $\%$ & $\mathbf{n}$ & $\%$ & $\mathbf{n}$ & $\%$ \\
\hline $\begin{array}{c}\text { Tidak } \\
\text { Cemas }\end{array}$ & - & - & 3 & 10,71 & - & - & - & - & 1 & 3,57 & - & - & 1 & 3,57 & 5 & 17,85 \\
\hline Ringan & - & - & - & - & 1 & 3,57 & 2 & 7,14 & 1 & 3,57 & - & - & - & - & 4 & 14,28 \\
\hline Sedang & - & - & 1 & 3,57 & 1 & 3,57 & - & - & - & - & - & - & - & - & 2 & 7,14 \\
\hline Berat & 5 & 17,85 & 6 & 21,46 & 4 & 14,28 & 1 & 3,57 & - & - & 1 & 3,57 & - & - & 17 & 60,69 \\
\hline Total & 5 & 17,85 & 10 & 35,74 & 6 & 21,42 & 3 & 10,71 & 2 & 7,14 & 1 & 3,57 & 1 & 3,57 & 28 & 100 \\
\hline
\end{tabular}

Data pada Tabel 3 pasien anak berjenis kelamin laki - laki yang berumur 6 tahun terdapat 1 sampel (4,54\%) yang tidak mengalami kecemasan, 1 sampel (4,54\%) mengalami cemas ringan, tidak ada sampel untuk yang mengalami cemas sedang, dan terdapat 1 sampel $(4,54 \%)$ pada anak yang mengalami cemas berat. Pada anak laki - laki yang berumur 7 tahun terdapat 2 sampel $(9,09 \%)$ yang tidak mengalami kecemasan, 1 sampel (4,54\%) mengalami cemas ringan, tidak ada sampel untuk cemas sedang, dan 2 sampel (9,09\%) untuk yang mengalami cemas berat. Pada anak umur 8 tahun tidak terdapat sampel untuk yang tidak mengalami kecemasan, masing 
- masing 1 sampel (4,54\%) mengalami cemas ringan dan cemas sedang, dan tidak terdapat sampel untuk yang mengalami cemas berat. Untuk anak berumur 9 tahun terdapat 1 sampel (4,54\%) yang tidak mengalami kecemasan, dan tidak terdapat sampel untuk masing - masing cemas ringan, cemas sedang, dan cemas berat.

Pada anak berumur 10 tahun terdapat masing - masing 2 sampel untuk anak yang tidak mengalami kecemasan dan cemas ringan, tidak ada sampel untuk cemas sedang, dan terdapat 2 sampel $(9,09 \%)$ untuk anak cemas berat. Untuk anak berumur 11 tahun tidak terdapat sampel untuk anak yang tidak mengalami kecemasan, 1 sampel (4,54\%) mengalami kecemasan kecemasan ringan, dan masing - masing kecemasan sedang dan kecemasan berat tidak memiliki sampel. Pada anak berumur 12 tahun terdapat 3 sampel (13,69\%) tidak mengalami kecemasan, tidak terdapat sampel pada masing - masing tingkat kecemasan ringan dan kecemasan sedang, terdapat 1 sampel (4,54\%) pada tingkat kecemasan berat.

Tabel 3. Distribusi subjek penelitian tingkat kecemasan berdasarkan jenis kelamin laki-laki

\begin{tabular}{|c|c|c|c|c|c|c|c|c|c|c|c|c|c|c|c|c|}
\hline \multirow{3}{*}{$\begin{array}{c}\text { Tingkat } \\
\text { Kecemasan }\end{array}$} & \multicolumn{14}{|c|}{ Laki - Laki } & \multicolumn{2}{|c|}{ Total } \\
\hline & \multicolumn{2}{|r|}{6} & \multicolumn{2}{|r|}{7} & \multicolumn{2}{|c|}{8} & \multicolumn{2}{|r|}{9} & \multicolumn{2}{|r|}{10} & \multicolumn{2}{|r|}{11} & \multicolumn{2}{|r|}{12} & \multirow{2}{*}{$\mathbf{n}$} & \multirow{2}{*}{$\%$} \\
\hline & $\mathbf{n}$ & $\%$ & $\mathbf{N}$ & $\%$ & $\mathbf{n}$ & $\%$ & $\mathbf{n}$ & $\%$ & $\mathbf{n}$ & $\%$ & $\mathbf{n}$ & $\%$ & $\mathbf{n}$ & $\%$ & & \\
\hline $\begin{array}{l}\text { Tidak } \\
\text { Cemas }\end{array}$ & 1 & 4,54 & 2 & 9,09 & - & - & 1 & 4,54 & 2 & 9,09 & - & - & 3 & 13,69 & 9 & 40,95 \\
\hline Ringan & 1 & 4,54 & 1 & 4,54 & 1 & 4,54 & - & - & 2 & 9,09 & 1 & 4,54 & - & - & 6 & 27,27 \\
\hline Sedang & - & - & - & - & 1 & 4,54 & - & - & - & - & - & - & - & - & 1 & 4,54 \\
\hline Berat & 1 & 4,54 & 2 & 9,09 & - & - & - & - & 2 & 9,09 & - & - & 1 & 4,54 & 6 & 27,27 \\
\hline Total & 3 & 13,62 & 5 & 22,72 & 2 & 9.08 & 1 & 4,54 & 6 & 27,27 & 1 & 4,54 & 4 & 18,23 & 22 & 100 \\
\hline
\end{tabular}

Tabel 4. Distribusi subjek penelitian tingkat kecemasan berdasarkan umur

\begin{tabular}{ccccccccccc}
\hline \multirow{2}{*}{$\begin{array}{c}\text { Tingkat } \\
\text { Kecemasan }\end{array}$} & $\mathbf{6}$ & $\mathbf{7}$ & $\mathbf{8}$ & $\mathbf{9}$ & $\mathbf{1 0}$ & $\mathbf{1 1}$ & $\mathbf{1 2}$ & $\mathbf{N}$ & $\mathbf{\%}$ \\
\cline { 2 - 10 } & 1 & 5 & - & 1 & 3 & - & 4 & 14 & 28 \\
\hline Tidak Cemas & 1 & 1 & 2 & 2 & 3 & 1 & - & 10 & 20 \\
Cemas Ringan & - & 1 & 2 & - & - & - & - & 3 & 6 \\
Cemas Sedang & 6 & 8 & 4 & 1 & 2 & 1 & 1 & 23 & 46 \\
Cemas Berat & 8 & 15 & 8 & 4 & 8 & 2 & 5 & 50 & 100 \\
\hline Total & & & & & & & & & &
\end{tabular}

Data pada Tabel 4 golongan tidak cemas terdapat 1 sampel pada anak berumur 6 tahun, 5 sampel untuk anak berumur 7 tahun, tidak ada sampel untuk anak berumur 8 tahun, 1 sampel untuk anak berumur 9 tahun, 3 sampel untuk yang berumur 10 tahun tidak ada sampel untuk anak berumur 11 tahun dan 4 sampel untuk anak berumur 12 tahun. Total sampel pada golongan yang tidak merasa cemas terdapat
14 sampel (28\%). Pada golongan cemas ringan masing - masing terdapat 1 sampel untuk anak yang berumur 6,7 dan 11 tahun, masing - masing 2 sampel untuk anak yang berumur 8 dan 9 tahun, 3 sampel untuk anak berumur 10 tahun, dan tidak ada sampel untuk anak berumur 12 tahun. Total sampel pada golongan cemas ringan terdapat 10 sampel (20\%). Pada golongan cemas sedang tidak terdapat sampel pada 
anak berumur 6, 9, 10, 11, dan 12 tahun, terdapat 1 sampel pada anka berumur 7 tahun, dan 2 sampel pada anak berumur 8 tahun. Total sampel pada golongan cemas sedang terdapat 3 sampel (6\%). Pada anak dengan golongan cemas berat terdapat 6 sampel pada anak berumur 6 tahun, 8 sampel pada anak berumur 7 tahun, 4 sampel pada anak berumur 8 tahun, masing - masing 1 sampel pada anak berumur 9, 11 dan 12 tahun, dan 2 sampel pada anak berumur 10 tahun. Total sampel pada golongan cemas berat terdapat 23 sampel (46\%).

\section{BAHASAN}

Hasil pembahasan tentang tingkat kecemasan berdasarkan umur dan jenis kelamin yang ada pada tabel 1 menunjukan dari 50 sampel, sebanyak 28 sampel (56\%) berjenis kelamin perempuan dan 22 sampel (44\%) berjenis kelamin laki - laki. Penulis juga mendapati hasil bahwa jenis kelamin mempengaruhi tingkat kecemasan pada anak-anak yang melakukan prosedur penambalan gigi. Selama penelitian, penulis mendapatkan dari 28 sampel berjenis kelamin perempuan ada 5 sampel $(17,85 \%)$ yang tidak mengalami kecemasan, sedangkan pada laki - laki penulis mendapatkan 9 sampel (40, 95\%) yang tidak mengalami kecemasan dari 22 sampel berjenis kelamin laki - laki.

Sampel yang mengalami tingkat cemas ringan pada perempuan terdapat 4 sampel $(14,28 \%)$ dari 28 sampel berjenis kelamin perempuan, sedangkan pada jenis kelamin laki-laki terdapat 6 sampel $(27,27 \%)$ yang mengalami cemas ringan dari 22 sampel berjenis kelamin laki - laki. Sampel yang mengalami tingkat cemas sedang pada perempuan terdapat 2 sampel (7,14\%), sedangkan sampel pada laki-laki yang mengalami tingkat cemas sedang terdapat 1 sampel (4,54\%), sedangkan yang mengalami tingkat cemas berat pada jenis kelamin perempuan terdapat 17 sampel (60,69\%), sedangkan di tingkat cemas berat berjenis kelamin laki-laki terdapat 6 sampel (27,27\%). Penulis berasumsi bahwa hal ini membuktikan jenis kelamin perempuan lebih rentan mengalami kecemasan daripada yang berjenis kelamin laki-laki terhadap prosedur penambalan gigi.

Hasil penelitian ini didukung oleh penelitian yang dilakukan oleh Wael dkk yang menemukan bahwa persentase wanita $(13,17 \%)$ yang merasa cemas lebih banyak daripada pria (12,29\%). Pada penelitian Bushra dkk di Pakistan juga menemukan bahwa kecemasan lebih banyak terjadi pada wanita daripada pria dengan perbandingan $1: 5 .^{9}$

Wong dan Donna (2008) juga menyatakan dalam buku Ajar Keperawatan Pediatrik bahwa anak perempuan lebih sering dan cenderung mengekspresikan kecemasan yang berlebihan seperti lebih mudah tertekan, kurang sabar, dan mudah mengeluarkan air mata. ${ }^{10}$

Berdasarkan hasil penelitian, penulis menemukan bahwa ketika operator akan menyiapkan alat-alat penambalan gigi, pasien anak yang berjenis kelamin perempuan terlihat lebih cemas dan takut daripada pasien anak yang berjenis kelamin laki-laki. Selama penelitian penulis melihat bahwa rasa cemas diekspresikan oleh pasien anak dengan berbagai cara seperti langsung menolak untuk memasuki ruang praktek dokter gigi, tidak mau untuk duduk di dental chair, menangis, menjerit, bahkan memberontak.

Hasil penelitian ini didukung oleh penelitian yang dilakukan Mario Hertanto (2009) yang mengobservasi 200 pasien dental anak di SD Pelangi Kasih,Theresia, dan SD Negeri Pegangsaan 01 mendapatkan bahwa rasa cemas terhadap perawatan gigi bisa disebabkan oleh alatalat kedokteran gigi. Kecemasan terus terjadi karena tidak adanya peran khusus dari orang tua yang tidak memperhatikan dan tidak memberikan dukungan pada anaknya untuk diberikan perawatan dari dokter gigi. ${ }^{11}$

Distribusi tingkat kecemasan berdasarkan usia menunjukan persentase paling tinggi pada usia 6 dan 7 tahun dengan 14 sampel, sedangkan kelompok umur 8 - 10 tahun terdapat 7 sampel, dan kelompok umur yang lebih tinggi yaitu 
umur 11 - 12 tahun hanya terdapat 2 sampel.

Di antara anak usia $6-7$ tahun anak akan sering berhubungan dengan perawatan dental karena pada rentang usia ini banyak gigi permanen erupsi mulai dari molar pertama sehingga besar kemungkinan anak akan di hadapkan dengan pengalaman pertamanya mengunjungi dokter gigi sehingga menimbulkan kecemasan yang berlebihan. $^{12}$

Anak pada usia 8-10 tahun mereka sudah bisa untuk mengekspresikan apa yang mereka rasakan dan cenderung bisa mengontrol apa yang mereka rasakan, sedangkan anak yang berumur $11-12$ tahun ke atas mereka sudah bisa membedakan, mempersepsikan sesuatu dan mempertimbangkan antara tujuan tingkah laku dan konsekuensi yang akan mereka hadapi dalam perawatan gigi. ${ }^{13,14}$

Faktor umur sangat mempengaruhi perilaku anak terhadap perawatan gigi, anak dengan usia yang muda seperti pada umur 6 dan 7 tahun sering menunjukan perilaku yang kurang kooperatif terhadap perawatan gigi karena anak dengan umur yang lebih muda menunjukan ekspresi takut yang tinggi terhadap perawatan gigi. ${ }^{15,16}$ Hal ini membuktikan bahwa umur bisa menjadi faktor tingkat kecemasan pasien anak seperti penelitian yang dilakukan oleh Turner dan Ahmad yang menjelaskan bahwa semakin tinggi tingkatan umur maka tingkat kecemasan akan semakin rendah. ${ }^{17,18}$

\section{SIMPULAN}

1. Hasil penelitian tingkat kecemasan berdasarkan jenis kelamin pada 50 orang didapatkan tingkat kecemasan berat lebih tinggi pada pasien anak berjenis kelamin perempuan dengan jumlah 17 orang $(60,69 \%)$ dari 28 anak perempuan yang menjadi responden, dibandingkan pasien anak berjenis kelamin laki-laki dengan jumlah 6 orang (27,27\%) dari 22 anak laki - laki yang menjadi responden.

2. Hasil penelitian tingkat kecemasan berat berdasarkan umur didapatkan paling banyak pada pasien anak yang berumur paling muda yaitu anak yang berumur 6 tahun sebanyak 6 orang yang mengalami cemas berat dari 8 pasien berumur 6 tahun yang menjadi responden.

\section{SARAN}

1. Hasil penelitian dapat menjadi umpan balik bagi instansi kesehatan lainnya untuk meningkatkan pelayanan terutama pada penambalan gigi anak.

2. Perlu dilakukan penelitian serupa yang menggunakan sampel yang lebih besar lagi sehingga hasil yang dicapai lebih akurat.

\section{DAFTAR PUSTAKA}

1. Wahab AS, editor. Imu kesehatan anak. Jakarta: Buku Kedokteran Indonesia EGC, 2000; p.103.

2. Swartz MH, Buku ajar diagnostik fisik. Jakarta: Buku Kedokteran Indonesia EGC, 1995; p.21.

3. Maulani C, Enterpris J. Kiat merawat gigi anak. Jakarta: PT Elex Media Komputindo, 2005; p.53-55.

4. Arikunto S. Prosedur penelitian suatu pendekatan praktik. Jakarta: Rineka Cipta, 2010; p.43.

5. Semiun Y. Kesehatan mental 2. Yogyakarta: Kanisius, 2006; p.321.

6. Semiun Y. Teori kepribadian dan terapi psikoanalitik Freud. Yogyakarta: Kanisius, 2006; p.87-89.

7. Bertens K. Psikoanalisis Sigmund Freud. Jakarta: PT Gramedia Pustaka Utama, 2006; p.34.

8. Muttaqin A. Asuhan keperawatan klien dengan gangguan sistem persarafan. Jakarta: Salemba Medika, 2008; p.69.

9. Guyton A.C, Hall J.E. Fisiologi kedokteran. Alih bahasa. Irawati. Jakarta: EGC, 2008; p.182-3.

10. Wong, Donna L. Buku ajar Keperawatan Pediatrik.Jakarta: EGC,2008; p.27

11. Hertanto M. Perbedaan tingkat kecemasan dental berdasarkan usia dan jenis kelamin terhadap lingkungan perawatan dental pada anak usia 6 dan Elvira SD, Hadisukanto G, editor. Buku Ajar Psikiatri. Jakarta: Badan Penerbit FKUI, 2010; p. 250. 
12. Mohammad, et.al. Prevalence of Dental Anxiety and it's Relation to Age and Gender in Coastal Andhra (Visakhaptanam) Population, India. J Nat Sci Biol Med; 2014:5(2):409-14.

13. Susanto A. Perkembangan Anak Usia Dini. Ed.I. Jakarta: Kencana, 2011.

14. Sholihat N. Memahami Perkembangan dan Masalah Emosi Anak. [Monograph on the internet]. [cited 20 0ct 2012]. Available from : URL: http//www.Memahami/Perkem bangan/dan/Masalah/Emosi/Anak/c2/ AB/Neni/Sholihat/word.html.

15. Nurmini M. Rasa takut dan cemas terhadap perawatan gigi di SDN 20 Panyula Kab. Bone tahun 2010. Media kesehatan gigi. 2010. [cited 24 Feb 2015]. Available from http://isjd.pdii.lipi.gp.id/admin/jurnal/ ed2nov102836_2087-0051.pdf

16. Permatasari AS. (2014, September). Pola Perilaku Anak Terhadap Perawatan gigi dan Mulut, Puskesmas Sudiang Raya dan RSUD Kota Makasar 2014 [Skripsi]. Fakultas Kedokteran. Universitas Hasanuddin. Makasar, p.30

17. Turner S, Chambers SA, Freeman R. Measuring Dental Anxiety In Children With Complex And Additional Support Needs Using The Modified Child Dental Anxiety Scale (faces) (MCDASf). Journal of Disability and Oral Health. 2012:310.

18. Ahmadi HA Sholeh M. Psikologi Perkembangan. Jakarta: Rineke Cipta, 2005; p.119. 